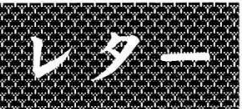

\title{
ラマン分光法によるウランの吸着挙動に関する研究 一銀コロイドおよび金コロイドへの吸着一
}

\author{
津島悟 ·長崎晋也·田中知 ·鈴木篤之 \\ 東京大学大学院工学系研究科システム量子工学専攻 文京区本郷（テ113） \\ (1997年 3 月 12 日 受理) \\ キーワード：ラマン分光法, ウラン, 吸着, 銀コロイド, 金コロイド \\ Raman Spectroscopic Study of Uranium Adsorption \\ -Adsorption onto Ag and Au Colloidal Particles-
}

Satoru Tsushima, Shinya NAgASAKI, Satoru TANAKA, and Atsuyuki SuzUki

Department of Quantum Engineering and Systems Science, School of Engineering, University of Tokyo, Hongo, Bunkyo, Tokyo 113

(Received March 12, 1997)

Keyword: Raman spectroscopy, uranium, adsorption, Ag colloid, Au colloid

\begin{abstract}
Raman spectra of uranium loaded $\mathrm{Ag}$ and Au colloidal particles have been measured. It was observed that Raman active symmetric stretching frequency of uranyl ion at $870 \mathrm{~cm}^{-1}$ shifts to smaller wavenumber when adsorbed onto $\mathrm{Ag}$ and $\mathrm{Au}$ particles. The shift depends on $\mathrm{pH}$ of the solution for $\mathrm{Ag}$ particles, but not for $\mathrm{Au}$ particles. The notion that uranium adsorption involves ligand liberation was thus confirmed for Ag particles, while it was discounted for Au particles.
\end{abstract}

\section{1. 緒言}

わが国では, 高レベル放射性廃棄物の最終処分方法とし て, 地質学的に安定な深地層中に埋設処分する地層処分が 最も有力視されている. 高レベル放射性廃棄物地層処分に おいて最も懸念されることは, 放射性核種が崩壊し, その 毒性が天然レベルになで減衰する以前に, 人間の生活圏に 達することである. そのため, 地層処分の安全評価にあた っては, 放射性元素の地球化学的挙動を正確に把握する必 要がある. 本報に抢いては, ウランの金属コロイドへの吸 着についてえられた知見を報告する。

ウランは通常の酸化性溶液では 6 価として存在し, $\mathrm{pH}$ が 4 より低い酸性溶液では $\mathrm{UO}_{2}^{2+}$ として存在する.しか し, $\mathrm{pH}$ が 4 付近より高くなると, 加水分解生成物を形成 しはじめる。 また，中性付近以上の $\mathrm{pH}$ 領域に打いては， 溶存している炭酸イオンにより炭酸錯体を形成しはじめ る.このことから, ウランが吸着の際に, 加水分解生成物 や炭酸錯体を形成したまま吸着しているのか，あるいは配
位子の解放を伴いながら吸着しているのかに，大きな関心 が持たれてきた。しかし，現在表面分析に用いられている 手法の多くは試料を高真空状態に沶かねばならず，吸着界 面のin-situな観測が成立しえない。一方, 近年注目を集 めている広域 $\mathrm{X}$ 線吸收微細構造解析法, X 線吸収端微細 構造解析法, 赤外分光法, ラマン分光法, 光音響分光法な ぞを用いれば，固液界面をin-situに観測することが可能 となる.しかし, ウランのラマンスペクトルの測定の報告 は少なく，体系的にまとめら机たものは事実上 Maya ら の研究のみである1-3). 本研究では, ウランの銀コロイド および金コロイドへの吸着実験を幅広い $\mathrm{pH}$ 域でおこな い, そのラマンスペクトルの観測を行った.

\section{2. 実験}

実験は大気開放系でおこなった. Lee-Meisel の手法4)で 作製した銀コロイド，およびChow らの手法5)で作製した 金コロイド $5 \mathrm{ml}$ をパイレックスチューブに入れ， $0.1 \mathrm{M}$ 硝酸门ラニル溶液 $30 \mu l$ を加え, 硝酸溶液抢上び水酸化十 


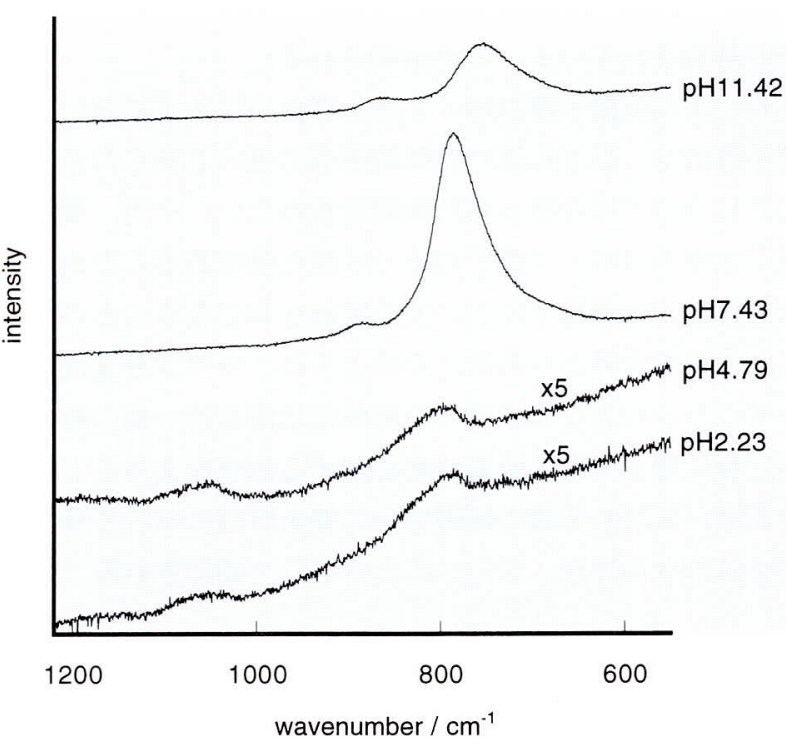

Fig. 1 Raman spectra of uranium loaded Ag colloidal particles.

トリウム溶液により $\mathrm{pH}$ 調整を行った。これを恒温振盪器 に入れ，温度 $25 \pm 0.1^{\circ} \mathrm{C} て ゙ 15 \sim 48$ 時間恒温振湯した．振湯 後, $\mathrm{pH}$ 測定を行い, 約 $4 \mathrm{ml}$ を 4 面透明石英セルに採取 して，そのラマンスペクトルの測定を行った．測定には励

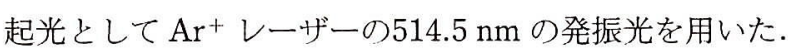

\section{3. 結果及び考察}

Fig. 1 にウランを銀コロイドに吸着させた後に測定した ラマンスペクトルを, $\mathrm{pH} 2.23,4.79,7.43$ 抢よび 11.42 の ものについて示す．Fig. 2 にはウランを金コロイドに吸着 させた後に測定したラマンスペクトルを, $\mathrm{pH} 2.29$ 抢よび 10.36のものについて示す.

Fig. 1, Fig. 2 双方とも， $1050 \mathrm{~cm}^{-1}$ 付近，抢よび750 $800 \mathrm{~cm}^{-1}$ 付近にピークが観測された．前者は硝酸イオン に㷌属することから，後者が $\mathrm{U}=0$ の振動に帰属するも のと考えられる. Fig. 3 に U =0 振動のバンドの位置を銀 コロイド，金コロイド双方についてまとめたものを示す。 $\mathrm{UO}_{2}^{2+}$ のラマン活性な $\mathrm{U}=\mathrm{O}$ 対称伸縮振動は $870 \mathrm{~cm}^{-1}$ に あることが知られて扔り，銀コロイド，金コロイド双方と も吸着に伴いラマンバンドが大きく短波数側にシフトして している.このことから, 両者の間で強い相互作用が起き ていることが示唆される。このような相互作用は, 吸着物 質からウラニルへの電子密度の移動に伴って起こると考え られる。

まず銀コロイドの結果について考察する。 $\mathrm{pH}$ 依存性 は, $\mathrm{pH} 2.23$ から $\mathrm{pH} 4.79$ までラマンバンドは $798 \mathrm{~cm}^{-1}$ と 一定である. しかし実際には, $\mathrm{pH} 4$ 以上では $\mathrm{UO}_{2}^{2+}$ が加 水分解を始め, $\mathrm{UO}_{2}(\mathrm{OH})_{2}^{0}$ が生成し始める. したがって, この結果により $\mathrm{UO}_{2}^{2+}$ と $\mathrm{UO}_{2}(\mathrm{OH})_{2}^{0}$ が吸着に際して同じ

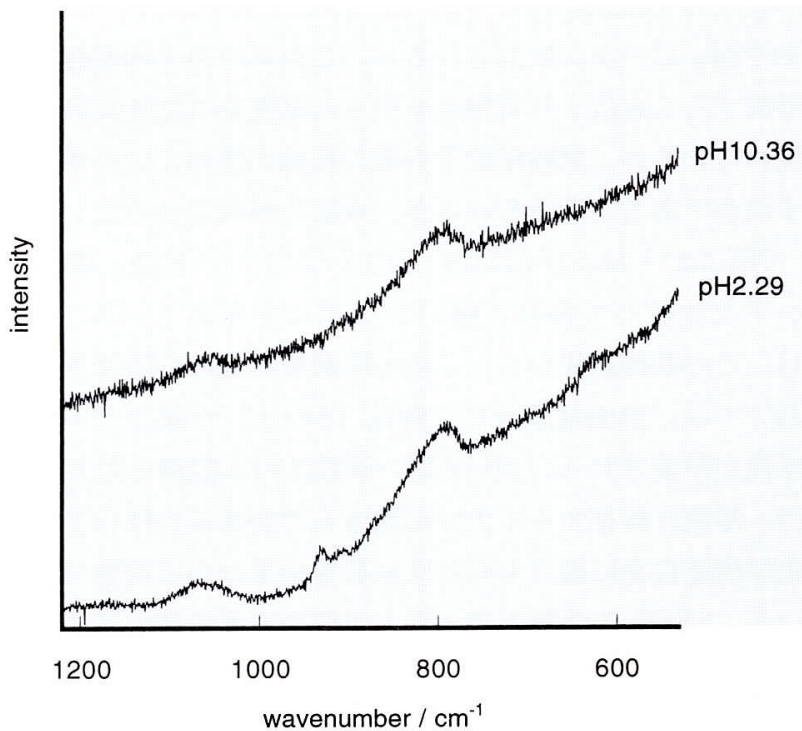

Fig. 2 Raman spectra of uranium loaded Au colloidal particles.

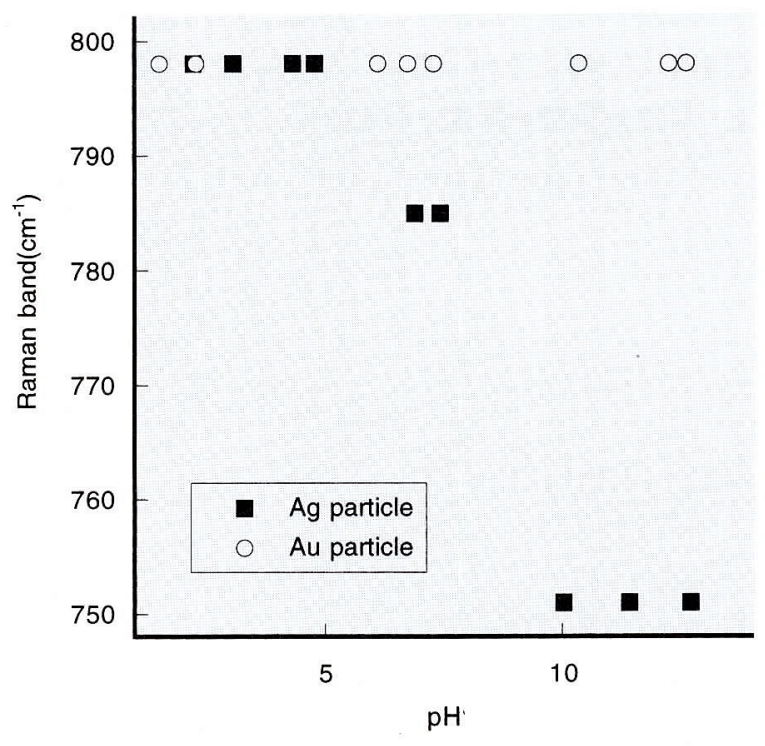

Fig. $3 \mathrm{pH}$ dependency of $\mathrm{U}=\mathrm{O}$ symmetric stretching frequency of adsorbed uranium.

化学形となっていることが示唆される.このことから， $\mathrm{UO}_{2}(\mathrm{OH})_{2}^{0}$ が吸着の際に配位子を解放して吸着している ことが考えられる.

$\mathrm{pH} 6.90$ 抢よび $\mathrm{pH} 7.43$ ではラマンバンドは $785 \mathrm{~cm}^{-1}$ に 移るが，この範囲では加水分解生成物が減少し，代わって 炭酸錯体である $\mathrm{UO}_{2}\left(\mathrm{CO}_{3}\right)_{2}^{2-}$ が支配的となる。 あた， $\mathrm{pH}$ 9.85 以上ではバンドは $751 \mathrm{~cm}^{-1}$ に観測されるが，この領 域では殆どのウランは $\mathrm{UO}_{2}\left(\mathrm{CO}_{3}\right)_{3}^{4}$ 一して存在する。し たがって, $785 \mathrm{~cm}^{-1}$ のバンドは $\mathrm{UO}_{2}\left(\mathrm{CO}_{3}\right)_{2}^{2-} に, 751$ $\mathrm{cm}^{-1}$ のバンドは $\mathrm{UO}_{2}\left(\mathrm{CO}_{3}\right)_{3}^{4-}$ に対応するものと考えら れ，ウランは炭酸錯体を形成したまま銀コロイドに吸着し ていると考えられる.さらに $\mathrm{pH} 6.90$ 抢よび $\mathrm{pH} 7.43$ の 
ペクトルでは $885 \mathrm{~cm}^{-1} に, \mathrm{pH} 9.85$ 以上では $870 \mathrm{~cm}^{-1}$ に やや弱いピークが観測されるが，これはウラニルが錯体を 形成することにより対称性を失った結果赤外活性な振動が 現れているか，炭酸配位子自身の振動が現れているかのい ずれかであると考えられるが，今後の検討を急ぎたい．

$785 \mathrm{~cm}^{-1}$ 打よび751 $\mathrm{cm}^{-1}$ の 2 つのバンドは, 他とバ ンドと比較して極めて強いシグナルを与えている（Fig. 1).この観測結果から,この $\mathrm{pH}$ 領域に抢ける吸着界面に 沶いては, 表面增強ラマン散乱（SERS）が起きている可 能性が示唆される. $\mathrm{pH}$ が高い領域にのみ観測される理由 が，溶液に溶存するイオンに因るものかあるいはウランの 化学構造自身に因るものかは本研究結果からは明確ではな いが，SERSの機構を考える上で極めて興味深い現象であ ると思われる。

次に金コロイドの結果について考える．金コロイドと銀 コロイドとの大きな違いは，金コロイドに対する吸着で は, $\mathrm{pH} 1.52$ から $\mathrm{pH} 12.62$ までと幅広い範囲の $\mathrm{pH}$ に対し て同じ798 $\mathrm{cm}^{-1}$ にラマンバンドを示していることであり, ウランは金コロイドに対して, 溶液の $\mathrm{pH}$ に関係なく同じ 結合をしていることがわかる．実際には前述の通り $\mathrm{pH} 4$ 以上では加水分解や錯体を形成を行っていることから，金
コロイドに対する吸着では，吸着にともないすべての配位 子が解放されていることが示唆される.

バンドの位置が銀コロイド抢よび金コロイドに抢いて異 なる原因は, 以上に述べた吸着構造の違いと見られるが， これについては今後さらに検討を重ねたい，一方，実際の 地下水中のコロイド粒子の多くは酸化物であることから， 今後は酸化物微粒子についての実験を抢こなうことが求め られるものと考えられる.このように，ラマン分光法を用 いてウランのみならず種々の高酸化状態を持つ他の超ウラ ン元素に対しても, 吸着状態に関する知見をえることがで きれば, 放射性元素の地層処分の安全評価における分光学 的手法の有用性が，さらに広まるものと期待される。

\section{文献}

1) L. Maya and G. M. Begun: J. Inorg. Nucl. Chem. 43, 2827 (1981).

2) L. Maya: Inorg. Chem. 21, 2895 (1982).

3) L. Maya: Radiochim. Acta 31, 147 (1982).

4) P. C. Lee and D. J. Meisel: J. Phys. Chem. 86, 3391 (1982).

5) M. K. Chow and C. F. Zukoski: J. Colloid Interface Sci. 165, 97 (1994). 